\title{
Camus eta Sartreren eragina zenbait euskal idazlerengan
}

\section{The influence of Camus and Sartre on some Basque writers}

\author{
PAKO SUduPE ELORZA* \\ Pasaiako Udala (Euskara Saila)
}

\begin{abstract}
LABURPENA. Unamunorekin batean, A. Camusek eta J-P. Sartrek ere eragin handia izan zuten 50eko hamarkadatik aurrera gure intelligentsia ttipian, hots, frantziskotarrengan (lehenik, Bastarrikarengan) eta, halaber, Txillardegi, Juan San Martin, E. Lopez Adan eta Joxe Azurmendirengan-eta; eta eragin hori giltzarri izan zen fede katolikoan oinarrituriko euskal kultura tradizionaletik euskal kultura moderno laikoagora igarotzeko. Hasieran Camus izan zen eragile handiena, eta geroago Sartre. Lan honetan Camus eta Sartreren arteko harreman pertsonal-intelektuala arakatzetik abiatzen naiz, eta ondotik haien eraginaren nondik norako nagusiak azaltzera egiten dugu, existentzialismoa, erlijioa eta morala direla ardatz. Eta, horrekin batean, biolentziaren bidezkotasunaz Parisen II. Mundu Gerraren ondotik egindako hausnarketa jarraitzen dugu. Testuingurua, orduan, komunistek Iraultza egiteko zuten xedea zen. Errusian arrakasta izandakoak zergatik ez zuen arrakasta izan behar Frantzian? PCF alderdi komunista frantsesak 800.000 afiliatu zituen 1946an, eta eragin gaitza. Lopez Adanen iritzia jaso ondotik, axola handikoak iruditzen zaizkigun Joxe Azurmendiren ideia hauekin amaitzen dugu idatzia: gai horretan, Sartre eta Camus soluzio baten bila haztamuka ibili dira. Ez dira erlijiosoki dogmatikoak izan Ghandiren erara. Bortxarekiko behar dugun morala egiteko dago, eta egiteko egongo da beti, horrentzat ez daudelako hamar mandamenduak betiko zizelkatuak harrizko taulan: erantzuna gizarte bakoitzak eta aro bakoitzak beretzat erabaki — hautatu — beharrekoa baita.
\end{abstract}

GAKO-HITZAK: existentzialismoa; Camus; Sartre; erlijioa; morala; biolentzia.

\begin{abstract}
Together with Unamuno, both A. Camus and J-P. Sartre had a lot of influence from the 50s of the last century on Basque reduced intelligentsia, that is, on the Franciscans (first, on Bastarrika) and on Txillardegi, Juan San Martín, E. López Adán and Joxe Azurmendi, among others. This influence was crucial to move from the traditional Basque culture based on the Catholic faith to a more secular Basque culture. At first, Camus was the most influential; Sartre came later. This work starts by exploring the personal and intellectual relationship between Camus and Sartre; then I present the main themes of their impact dealing with existentialism, religion and morals. And along with it, I follow the debate about the legitimacy of violence that took place in Paris after World War II. The context was communists's revolutionary goals: If it succeeded in Russia why would it not succeed in France? In 1946, PCF (the French Communist Party) had 800,000 members, and its influence was enormous. After presenting López Adán's view, the paper ends by gathering some ideas by Joxe Azurmendi on the topic of violence. Sartre and Camus were not religiously dogmatic like Gandhi. The morals needed with respect to violence needs to be built; and it will always be because there are no tablets of the ten commandments, and the answer corresponds to to each society in its own time.
\end{abstract}

KEYWORDS: existentialism; Camus; Sartre; religion; moral; violence.

\footnotetext{
* Harremanetan jartzeko / Corresponding author: Pako Sudupe Elorza. Etxeberri, 7, 5-C (Hernani) - pselorza@gmail.com https://orcid.org/

Nola aipatu / How to cite: Sudupe Elorza, Pako (2020). "Camus eta Sartreren eragina zenbait euskal idazlerengan», Gogoa, 21, 3-28. (https://doi.org/10.1387/gogoa.21626).

Jasoa: 2020-I-7. Onartua: 2020-III-30. Aurrena online argitaratua: 2020-IV-3.
}

ISSN 1577-9424 - eISSN 2444-3573 / (c) 2020 UPV/EHU

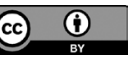

Lan hau Creative Commons Aitortu 4.0 Nazioartekoaren

lizentziapean dago 


\section{Sarrera}

Joxe Azurmendiren Oraingo gazte eroak (1998) liburua irakurrita jabetzen da bat oso ongi Albert Camusek eta Jean Paul Sartrek zer-nolako eragin gaitza izan zuten iragan mendeko 50eko hamarkadatik aurrera gure intelligentsia ttipian, bereziki belaunaldi zaharra(k) berri(ar)engandik bereizteko puntuan, fede katolikoan oinarrituriko euskal kultura tradizionaletik euskal kultura moderno laikoagora iragateko bilakabidean. Eta, horrenbestez, artikulu honen xedea izango da, euskal kontzientziara eta idazkuntzara 36ko gerraurrean iritsiak zirenen eta bereziki 50eko hamarkadan bildu ziren idazleen baitan, existentzialistek -Unamunok ere garrantzi itzela izan zuen Euskadi penintsularrean - eta guztiz ere Camusek eta Sartrek izandako garrantzia azaleratzea, eta egungo euskal intelligentsia beti ttipiak - herri ttipi bati dagokionez- interesgarritzat jotako memoria literario-intelektual eta politiko hori transmititzea.

\section{Camus eta Sartre}

Camusen biografia (1913-1960) eta obrak lerro batzuetara ekarririk, Aljeriako familia frantses apal batean munduratu zen. Urtebeteko haurra zela, aita lehen mundu gerran hil zitzaion; eta amak, berriz, garbiketak eginez ateratzen zuen bizimodua, eta irakurtzen ez zekien. Osaba-izebek hazi zuten Aljerren, Mediterraneo ondoko hiri eguzkitsuan, Belcourteko langile-auzo behartsuan, eta frantsesa bai, baina batez ere Aljeriako frantsesa (pied noir) sentitzen zen gaztetan, eta are helduaroan ere, Parisen biziagatik. Sartrerekin alderaturik, literatoa gehiago izan zen filosofoa baino - saiakera eta nobela filosofikoen egile, halere!- , eta, nahiz berak ez zion inoiz bere buruari existentzialista iritzi, halakotzat hartua izan zen, eta erlijio eta moral tradizionalaren kritiko gisa interpretatu eta gehienbat goretsi dute edo behinik behin begirunez tratatu dute euskal idazleek.

Aljerreko alderdi komunistako kide izan zen 1935etik 1937ra. Sartrerena ez bezala (Sartre existentzialismotik igaro zen marxismora, eta intelektual engaiatua izatera), Camusen existentzialismoa edo absurdoaren filosofia postmarxista zen, klase-borrokaz etsi ondokoa. Frantziaren okupazio garaian erresistentzian aritu zen 1943ko urritik aurrera, kazetari gisa —ez arma-ekintzetan-, Combat aldizkari klandestinoa ateratzen, eta, 1948an, Sartrerekin RDR (Rassemblement Démocratique Révolutionaire) alderdiaren mitin nagusian tribuna partekatu bazuen ere, alderdi baino gehiago ezkerreko mugimendu sozialista izan zen hark -PCFren estalinismoarekin kritiko eta SFIO sozialdemokratekin ere bai, AEB eta SESBekin bezala- ez zuen arrakastarik izan, eta Camus laster igaro zen antikomunismora, paristar adiskidearekin haserreturik. Aljeriako gerra luze-ankerrean, frantses eta Aljeriako herritar musulmanen arteko bizikidetzaren alde engaiatu zen; Sartre, aldiz, 
aljeriarren independentziaren alde, eta, hargatik, OASen errepresioa jasan zuen - bi bonba jarri zizkioten, nahiz eta ez zuten zauritu-.

Bere obra zabalagoa bada ere, guri Arrotza (2017 [1942]), Sisyforen mitoa (1992 [1942]) eta Izurria (1992 [1947]) interesatzen zaizkigu bereziki.

Sartrerengana etorriz, hark ere ez zuen aita ezagutu, baina zirkunstantzia komun hori gorabehera, oso haurtzaro eta gaztaro ezberdina (1905-1980) izan zuen Camusenaren aldean. Aitona-amonek eta amak hezi zuten Parisen familia burges batean; bereziki aitona alsaziarrak izan zuen eragin handia berarengan. Oso umetatik idazteari emanik, filosofia alemanaren eta zinemagintza estatubatuarraren eraginpean (Cohen-Solal 2005a), filosofia eta literatura existentzialetik marxismora eta intelektual engaiatua izatera igaro zen II. Mundu Gerratik aurrera, eta burgesiatik proletarioen aldera, ezkerraren posizioetan mugiturik aurrerantzean —gorago aipatu RDRren sozialismo ez-komunistatik abiaturik, 1952tik 1956ra komunismoarekin nahiko bat, eta Hungariako inbasiotik aurrera SESBekin kritiko baina AEBekin eta kapitalismoarekin are kritikoago, 1964an Nobel Sariari uko eginik, 1968ko matxinadarekin bat; 1971n, euskal borrokaren aldeko hitzaurre famatua idatzirik, eta sozialismo anarko airean amaiturik-.

Gorago adierazi bezala, Camus begirune handiagoaz tratatu zuten gerraurreko euskal idazleek Sartre baino; bereziki filosofia eta moralagatik kritikatu eta jorratu zuten paristarra, eta politika eta moralarekin, politika eta bortxarekin erlazionatu dute gerraondoko euskal idazleek, eta bereziki Txillardegirentzat erreferente miretsia izan da. Oso zeharka Goragalea (2003 [1938]) eta L'etre et le néant (1943, Izatea eta ezereza), eta guztiz ere beraren hautu politikoak izango ditugu iruzkingai.

Atzotik une baten gaurko egunetara etortzea zilegi bazait, egun ere arazo larriak baditugu, eta ez gutxi; esaterako, Europara egunero iristen diren iheslari eta migratzaileen arazoa, gerretatik eta miseriatik ihesi; aldaketa klimatikoarena ere gora doan afera global objektibo larria da egunotan; emakumeen aurkako bortxa; gutxiagoren arrangura den arlo batera etorririk, munduko hizkuntzen erdiak galtzear daude, gure elearen bizia batere bermatua ez, beste arazo larriak beste. Halere, Mendebaldean, batez ere Europan, ez gara I. eta II. Mundu Gerra ezin tragikoagoetatik atera berri, eta ez daude orduan bezain zabalduak larritasun eta larrimin existentzialak, ez gizartean eta ez intelligentsian ere. Ez dugu sinesten transzendentzian, oro har, baina ezaxola bizi gara. Camus, aldiz, konbentzitua zegoen gizakia ezin dela baliorik gabe bizi; batek bizitzea erabakitzen badu, horregatik beragatik balio bat baieztatzen du Camusen irudiko; bestela esanda, bizitzak merezi duela bizia izatea edota bizitzeko duina izan dadin lor daitekeela.

Camusek L'Homme révolté (1951, Gizon matxinatua) obran zioen bezala -liburu horrexek urrundu zuen Sartregandik-, iragan mendeko bigarren hamarkadatik aurrera, aurrekari gabeko gerra batek erroetaraino astindu 
zuen Alemania, eta galdutako gerraren eta angustia ekonomikoaren shockpean (Versailleseko Ituna, 1929ko crasha), ez zegoen zutik balio bat bera ere, eta bi gerren artean suizidio andana jazo ziren, suizidio izurritea izan zen. Gertaera hori gogoan, hobeki ulertzen da Camusek Sisyforen mitoa (1992 [1942]) izeneko obra hasi zuen bezala hastea; zinez arazo filosofiko serio bakarra dago: suizidioa; aditzera emanik bizitzak bizitzea merezi duen epaitzea eta filosofiaren funtsezko arazoari erantzutea baliokideak direla.

Bizitzak bizitzea merezi duen, bizitzaren absurdoa, ezereza... horiek ziren garaiko gaiak, existentzialistatzat ezagutzen direnak — horregatik alde friboloa baztertu gabe; areagotuz hain segur!; gauza jakina da Camus eta Sartre biak ala biak emakumezaleak zirela, eta Pariseko gauetan parrandan ibilzaleak oso! (Txillardegi 2007)—. Sartrek bezala Camusek ez zuen Jainkoan sinesten, baina, berak 1956an elkarrizketa baten agertu zuen bezala, horregatik ez zen ateoa, eta Sartre bai.

Howard Mumma AEBetako eliza metodistaren artzainak Camusekin hainbat elkarrizketa izan zituen 50eko hamarkadan (Mumma 2005), eta horietako batean esan zion ezen, Sartrerekin lehenbizikoz elkartu zenean, Sartre eta biak bat etorri zirela Jainkoa eztabaidatik kanpo utzi behar zutela, nahiz eta Camusek berak beti utzi izan zion posibilitate bat irekia gizakia baino goragoko zerbaiti. Aljeriako frantsesarentzat, lañoki esanda, Jainkoaren afera zen gauza bat modu behin betikoan inoiz jakitera iristerik izango ez duguna, eta, horrenbestez, bakarrik bageunde bezala bizi beharrean gara. Ez dago erreferentzia marko gorenik, betiereko egiarik ere ez, egia absoluturik; gizon eta emakume indibidualak bakarrik, zentzurik gabeko existentzian bide bat hautatzera kondenatuak, bizitza esentzia edo esanahiz hornitzearren ahal dutena eginez. Sartrek berak azaltzen zuen bezala: subjektibitateak izan behar du benetako filosofia ororen abiapuntua, existitzen den eta itxura batean absurdoa eta zentzurik gabea den gizabanakoarentzat.

Halaber, Camusek esan omen zion Mumma artzain metodistari ados zegoela Heideggerrek gizakiak existentziarekin egiten duen konfrontazioaren deskribapenarekin, eta nork bere burua existitzen den izaki gisa deskubritzearekin, hark abandonu egoera deitu zuenarekin, edota Sartrek nobela baten izenbururako erabilitako goragalearen sentimenduarekin.

Herri-sinestearen kontrara, esan omen zuen Camusek hark ez ziola inoiz bere buruari existentzialista deitu, baina beti identifikatu omen zen unibertso arrotz baten bakartua eta inpotente bizitzearen sentimenduarekin. Eta, Sartre bezala, Camus moraltasuna aurkitzen saiatzen zen, desesperazio itxuraren eta Jainkorik gabeko unibertso baten perspektibaren aurrean. Behin domingotar fraide talde bati esan omen zionez, partekatzen zuen haiekin gaizkiaren alderako izu berbera, baina ez zuen haiekin partekatzen haiek zuten Jainkoaren esperantza. Eta borrokan jarraitzen zuen haurrek sufritzen duten, eta haurrak hiltzen diren, unibertso honen aurka. 
Sartrerekin haserreturik bazegoen ere, oraindik asko zor ziola aitortzen zuen, baina bizitzari zentzua aurkitzeko ahaleginik ez egitea leporatzen zion. Haren erantzunek ez zuten gogobetetzen. H. Mummaren iritzian, Sartrek pentsatzen zuen erantzunak aurkituak zituela eta Camusek ez, eta, menturaz, inoiz ez zituen aurkituko. Camusentzat bizitza egia aurkitzeko, beti eskapatzen den egia aurkitzeko borroka etengabea zen, baina betiere ahalegintzeari uko egin gabe.

Camusek eta Sartrek elkarren ezagutza pertsonalak 1942-1943an egin zituzten, Frantzia Alemaniaren okupaziopean zenean. Baina lehenagotik espiritualki hurbilduak ziren elkarrengana. Sartrek Goragalea 1938an argitaratzean, artean kazetaritzan hasiberria zen Camusek kritika zorrotza bezain kartsua egin zion. Goretsi zituen Sartrek absurdoaz egindako deskribapenak; Antoine Roquentin protagonistaren bizitzaren ohiko egiturak kolapsatzen zihoazen eran, hari sortuz zihoakion larriminaren sentimendua eta haren ondoriozko goragalea. Camusek ez zuen bat egiten Sartreren negatibotasunean, Sartrek gizadiaren alderdi higuingarrienetan sakontzen baitzuen, gizakiaren handitasunaren zeinu batzuetan aurkitu beharrean etsitzeko arrazoiak. Eta halaber nahasirik uzten zuten Camus, artean Roquentinek esperantza aurkitzeko egindako saiakerek, baina estimatzen zituen Sartreren ideiak — hurbil sentitzen zen haren absurdoaren ideiatik - eta gozamena sortua zioten haren onestasunak eta berrikuntzarako gaitasunak (Aronson 2006).

Sartrek Paretaren kontra (1980 [1939]) plazaratzean, entusiazmoz goretsi zuen idazleak bizitzaren absurdoa nolako argitasunarekin islatu zuen, eta nola deskribatu zituen askatasuna alferrikako zuten pertsonaiak. Sartrek giza kondizio absurdoa deskribatu zuen, baina uko egin zion horregatik ikarak hartua sentitzeari. Filosofia eta irudiak orain orekan zeuden, Goragalean ez bezala.

Sartrek ere, bestalde, oso ongi hartu zuen Camusen Arrotza nobela. Sartreren biografo Cohen-Solalen arabera, Aljeriako frantsesaren nobela hark aukera eman zion paristarrari mugarik gabeko artikulu laudoriozkoa idazteko (Cohen-Solal 2005b). Besteak beste, adierazi zuen nobelan ez dagoela alferrikako xehetasunik, ez dagoela xehetasun bat bera ere geroago agertzen eta argumentuan enplegatzen ez denik. Eta, liburua itxitakoan, beste amaierarik ezin zuela izan ohartzen garela. Kausalitateaz gabetua izan den eta absurdo gisa aurkeztu den mundu honetan, gertaera ñimiñoenak du pisua. Ez dago gertaerarik heroia zigor kriminal handienekora bideratzen ez duenik. Arrotza obra klasikoa da Sartreren iritzian, obra metodikoa, absurdoari buruz eta absurdoaren aurka eratua.

Eta Izurria nobela ez gutxiago —ezaguna denez, alegoria bat da: Frantzia okupatzen ari ziren alemanak ziren izurria, 200 milioi europar zeuden alemanek oinperaturik, eta Izurria nobela gertatzen den Aljeriako Oranen berrehun mila biztanle izurriaren menpean-. Okupazio garaian idatzi zuen 
nobela hori Camusek eta berarentzat konpromisoaren eskuliburua izan zen, eta, Ronald Aronsonen arabera, Sartre gai politikoetan engaia zedin ere zerikusia izan zuen. Erabateko mehatxu baten aurrean, egin behar dena egiteko erabakitasun heroikotasun gutxikoa transmititzen du. Esate baterako, Rambert kazetariak berrogeialdian zegoen Oranen gelditzea erabakitzen du, eta ikasten du izurria borrokatzea guztiei dagokiela, ekintza kolektiboa eginez bakarrik burura daitekeela, egoerak eskatzen duenera plegatzea onarturik, eta ekintzari datxezkion arriskuak ere ontzat emanik. Sartrek AEBetan 1945. urte hasieran hitzaldia eman zuenean, jada irakurria zuen Izurriaren eskuizkribua, nahiz bi urte geroago argitaratu zuen Camusek, eta amerikarrentzat laburtu zuen eta handik irakaspen garrantzizkoak atera zituen. Protagonista nagusia den Rieux doktoreak lañotasunez eta ilusiorik gabe egiten zien desafio Gaizkiari eta Unibertsoari, eta giza espirituaren agintea berresten zuen bera baino handiagoko indarren aurka.

Camus eta Sartre 1943tik aurrera elkarren lagun hartuak izan ondotik, 1952an, betiko haserretu ziren Camusek L'Homme révolté (1951, Gizon matxinatua) plazaratzearekin, eta Sartre PCFra arras hurbiltzearekin. Autore batzuk enplegatu dira Camus eta Sartreren arteko adiskidetasuna eta elkarrengandiko urruntzea aztertzen, besteak beste, jada aipatua dugun Ronald Aronson estatubatuarra. Eta, gurean, euskal idazleentzat Camus eta Sartre biak ala biak izan dira garrantzizkoak, eta hein batean ildo bertsukoak, nahiz Sartre askoz gehiago kritikatua izan den bere filosofia ateoagatik, eta halaber, hautu politikoengatik ere.

Sartre hil zenean, lehenik, Lopez Adan Beltzak heldu zion Camus eta Sartre haserrearazi zituen dilemari; eta, berriki, hamarkada honetan bertan Joxe Azurmendik heldu dio gaiari, artikulu honen amaieran adieraziko dugun bezala.

\section{Jesuiten eskolakoak, fraide frantziskotarrak eta Txillardegi laikoa}

Frankismopean, 36ko gerraren eta II. Mundu Gerraren ondotik, alde batera, jakina denez, erlijio-debozioen goraldi bat gertatu zen; seminarioak bete ziren, eta Francoren gobernuak diruztaturik erlijioa hedatu zen Euskal Herri penintsularrean. Eta, Euskal Herri kontinentalean ere, II. Mundu Gerratik Frantzia burumakur samar ateragatik, sinesmen tradizionalak ez zuen galera handirik izan. Alabaina, Hegoaldean erlijioaren hedatze soziologiko horrekin batean, Eliza katolikoaren hierarkiak Francoren erregimena nola babesten eta bedeinkatzen zuen oharturik, kezka handiak sortu ziren hura ezin pairaturik, euskal erlijiosoen artean, eta, halaber, heziketa erlijiosoa jasorik ere, euskaldun eta ez espainol sentitzen ziren banaka batzuen artean, eta fede zalantzak. 
Hasiera batean ematen zuen fede-zalantzetatik, bizitzaren zentzuari buruzko eztabaidetatik kanpo geundela, gerrak gerra, fedea atxiki genuelako, baina laster hasi ziren pitzadurak azaltzen gazteak letren mundura agertzearekin. 50eko hamarkadaren lehen aroan, existentzialismoaren arbuioa eta betiko fedearen baieztapena izan ziren nagusi.

Eusebio Erkiagak infernura kondenaturiko Sartrek euskaldun fededunari sortzen zion nazka agertu zuen hitz neurtuetan. Existentzialistak ardi galduak ziren, eta, haien artzain Sartre are galduagoa, akerzain azkarra. Epikuroren txerriak ziren, udan arropa gutxirekin ipurdia agerian ibiltzen zirenak. Hona amaiera: «Agur ba, ene Sartre,/akerzai azkarra,/irri-karkaraz dozu/inpernuko garra! Ja-ja, ja-ja!...» (Erkiaga 1951: 21-22). Gomendatzen zien adimenaren bazkatzat San Agustinen Aitorkizunak (Orixe 1956) hartzea, otoi egitea izarrei begira, eta olerkiaren amaieran ziotson Sartreri irri-karkaraz zuela infernuko garra.

Erkiagak sentimenduz eta nardaz bezala, Zaitegik eta Orixek adimenaren indarrez heldu zioten Europan boladan zen existentzialismo filosofikoa jorratzeari. Zaitegik (1951), lehenik, nor eta Heidegger ulergaitza azaltzeari euskara garbiz ekinez. Inor desbidera ez zedin, artikuluaren sarreran argi azaldu zituen xedeak:

Yaungoikorik ez da ageri Heidegger'en azalkizun berrietan: arrezkero, ez siñesterik, ez itxaropenik, ezta goi-maitasunik ere. (...) Alare, iñolako aipua iritxi dizu Heidegger'ek, oraiñaldiko gertakizuei zor, iñolaz ere. (...) Beraz, yakintza orren saietsak oro aztertu ditzagun, eta aztarrenok lerrolerro azaldu-ala, euskaldunok ikusiko dugu gixon oiek baño gizonagoak gerala gure siñestez, gure itxaropenez ta gure goimaitasunez, ta euskaldunak gizonez iñori zorrik ez diola eguzkipean. (Zaitegi 1951: 25)

Esanguratsua da «orainaldiko gertakizunak» esapidea, gerren ondorio batez ere moralak iradokiz edo oroitaraziz, eta erronka bitxi hori, herri-probetako kirolarien ildokoa: inor baldin bada munduan euskaldun gizona baino gizonagorik...! Heideggeren filosofiaren arbuioa, han Jainkorik ageri ez delako, eta euskaldun gizonaren goresmena, bestetik, hark sineste, itxaropen eta goi-maitasun tradiziozkoa atxiki zezan. Kordoka zebilen seinale, noski!

Orixek, berriz, Heidegger ez ezik, Sartre eta Zubiri hartu zituen aztergai. Heidegger eta Sartre biak ala biak ezin kaxkarragoak jo zituen. Hona Sartreri buruz zioena:

Sartre'ren egi oiñarri ez da, berak askotan aipatzen dun au: «izatena lenago da izatea baiño», edo gertatzena lenago dala izatena baiño. (...) Izanean dan oro gertatzena baldin ba'da, edo Iainkorik ez da, edo guziok gera Iainko, Sartre, gertatu ori, bere buruaren iainkotxo diteke ta bere lege. Liburu kaxkarra du nik irakurri ori; oberik ez bide. Nolabaiteko pilosopu orrek ele-ederrera io omen du —ele itsusira esan- iñon diran ustelkeriak gertalekurako idatziz. (Orixe 1954: 64) 
Sartre erdipurdiko filosofoa eta ustelkeriaz jositako literaturaren egilea.

Alabaina, Txillardegik plazaratu zuen Leturiaren egunkari ezkutua (1957), Koldo Mitxelena aitabitxi zuela, hark egindako sarrerarekin, eta erreakzioa bestelakoa izan zen. Batzuek gaitzetsi zuten -Villasantek partez goretsi zuen, nobela psikologiko gisa, eta partez gaitzetsi, tesi jakinik ez omen duelako eta tonu garratza uzten duelako-, baina, Arantzazun bertan, beste batzuek goretsi zuten —Salbatore Mitxelenak Unamuno ta abendats (1958) liburuan; Bitoriano Gandiagak olerki baten, Elorrin (1989: 180) hain zuzen-.

Hori baino lehentxeago, Unamunorekin sortu zen polemika. Txillardegi, funtsean, Unamunoren alde, hark sortzen zuen egonezin existentzialaren alde, eta orduan Arantzazuko fraide ziren S. Berasaluze, I. Bereziartua eta I. Bastarrika aurka, bakoitza bere ñabardurekin. Baina labur-beharrez, Arantzazura mugatuz, gatozen Jakin euskarazko lehen kultur aldizkariaren sortzaile nagusi izandako Iñaki Bastarrikarengana. Txillardegirekin polemika garratza izan zuen, Leturiaren kontura. Iñaki Bastarrika ez zen Zaitegi edo Orixe; existentzialismoari kalteak ez ezik onurak ere ikusten baitzizkion:

Nolako ondorenak utzi dituan izaten-aburuak? Kaltegarriak geientsuak baiño etekintsuak ere bai. Ezta egia aburu onek utzi digun guztia zabarra danik. (...) Pizkundeak (Renacimiento) sortu zigun «giza-joera», izaten-aburuak jakintz-biotzean tinkotu du berauxe. Gizona duzu izaten-aburuan giltz-arazoa. Gizon bakoitza gañera, «zu ta ni». Gogo ta ezur-aragi uts besterik ez geranok. (...) Ez dira era berdiñean jokatzen, baño auxe dute denak elburu: gizonaren illundi oiek argitu. Auxen duzu aburu onen onurarik baliotsuena, jakintz-arazo guziak gizonagan bildu, beste ainbeste aburu ta jokabideen aurka. Auxen dut xede idazlantxo ontan (...) Aburu onen alderdi onuratsua nabarmendu. (Bastarrika 1956: 40-41)

Sartreren Existentzialismoa humanismo bat da (1988 [1946]) oroitarazten dute Iñaki Bastarrikaren esaldi horiek. Existentzialismoak bazituen alde txarrak, baina onak ere bai. Camusi Nobel Saria eman ziotenean, 1957an, hari buruz idatzi zuen. Erabat txalotu gabe, baina txaloak joz ere bai:

Suezia'ko Izkuntzaindiakin Camus'ek egungo problematika argi ta menez dakusanik aitor ezin ba'genezake ere, ezin uka Prantzia'n den irakurrienetakoa danik. Guziek bere elerti-jardunetan somatzen duten seriotasuna, egi-griña, iatortasuna ta «gizatasun» berezi ori baitipat, nabariegi dala derizkiot nolanai ukatzeko. La Peste eleberriaren argitaraldi guziak azaldu orduko suntsitu zirala ikusi besterik eztago, bere elergintzak izan duan artu beroa baiesteko, ta duan garrantzi aundia onartzeko. (...) «Albert Camus edo zintzotasun desesperatua», onatx labur eman A. Camus'en barrugiro osoa. Moeller ospetsuarenak dituzu itz oek, Littérature du Xx siècle et Christianisme liburu aipagarrian egille oni idazpurutzat ezarriak. Kidetu-edo nai lituzke A. Camus eta gizatasun edo iatorta- 
sun etsi oiek. Sustrai-sustraian jo dula uste dut Charles Moeller delako onek. Eta ez bakarrik gizon baten izaera-sustraian, gizaldi bateko gogoerdian baizik. (...) Iatorra benetan Camus'en elertiera. Naiz-ta aurreneko jardupenak erromantiku-kutsua eraman, egi-istaren lillurapean jarduna dugu arrezkero. La Peste delakoatik baitipat. Etzuten iñola guda-osteko esistentzialistek bere sare biguinetan atzi al izan gure egillea, beste ainbat bezela. Bolara batean bestera uste izan zan, eta ontara epaitu zuten, baiño ondo egiztatu da bere gogo-joerak oekin zerikusirik etzutela. (...) Ots aundiko gerta ziran Sartre'kin eutsi izandako eztabaidak, eta batez ere berarekin erabat ausi zuneko ura. Sartre berak aitortu du arrezkero bere pentsaerak artu-emanik eztula Camus'enarekin. (...) L'homme revolté (1951) du azkeneko eleberria. Gutxitan idatzi izan da ain gogor sasiideologi askoren aurka, ta ameskerizko Paradisu baten Izenean gizadia ondamendira daramatenen aurka baitipat. Orrialde gogoangarriak ditu batzu. Gure aldi oetan oi ez bezelako iatortasun sendo ta gardena dagerki. (...) Gizonaren zoriaren atergabeko aztertze onek ez ote du eskolatuko gure Camus, gizonari osertz zabalagoak aurkeztearren? Albert Camus Kristautasunera urbildu? Estu-estu. Zailla dirudi era ontako pentsalari bat balore absolutu batzuei zindo itsastea. Eztitu Camus'ek bere pentsaera-oinarriak sakonetik ikertu. Pentsa-aurretik eginik baidauka bere aukerapena. Ez digu Albert Camus'ek oraindik bere azken itza eman. (...) Itxaron dezagun siñeskor Jainkoaren grazi alguztidunean...Itxaropen aundiagorik ezin piztu bere burutapen-oiñarri lelo au duan gizon batek baiño. «Gizonarengan askoz gauza gehiago daude mirestekoak gutxiestekoak baino». ${ }^{1}$ (Bastarrika 1957a: 51-60)

Gure hitzez esanda, ezin du edo ez du erabat goretsi nahi Camus, egungo problematika argi eta autoritatez zekusanik ezin baitzen baieztatu, baina oso irakurria zen, Charles Moeller famatuak goretsia; ez zen Sartre eta existentzialistak bezalakoa, harekin haserretu zenez gero, eta kristautasunera hurbiltzea zaila bazen ere, esperantzarako zioak bazeuden, benetako federa itzul zitekeela pentsatzeko.

Bada, garai berean, Camusi Nobel Saria eman ondotik argitaratu zuen Txillardegik «Taupadak» izenburuko artikulua (1957). Camus Sartre baino gehiago Gide iruditzen zitzaion, limuria, lizuna, eta ez Sartre bezala lohia eta tristea. Hala ere, jendeak arriskutsutzat zeukala zioen. Ez zen sinestuna Aljeriako frantsesa: «Jakiña, Camus'ek ez du Jainkoa'gan siñisten: ez du aipatu ere egin beñere. Alde ontan Gide baño urrutiago dabil Jainkoa'gandik. Baña Sartre'gandik ere urruti dabil» (Txillardegi 1957b: 67).

\footnotetext{
1 Bastarrikaren aipuan frantsesez emanak zeuden barne-aipuak neronek itzuli ditut. Hemen jatorrizkoak:
}

«Albert Camus ou l'honnêteté désespérée.»

«Il y a plus de choses dans l'homme à admirer que de choses a mépriser.» 
Jende asko Frantzian eta beste lekutan Camusi Nobel Saria ematearen aurka zegoen, moralaren urratzailetzat zeukatelako. Txillardegik ukatzaile zekusan Aljeriako frantsesa. Sisifo da gizona, zioen, absurdua, bizitzaren bidegabekeria biribila. Haatik, bizitza bidegabea delako, hargatik beragatik izan behar dugu zoriontsu. Beltzegia jotzen zuen Camusen mundua. Eta konklusio moduan:

Guziarekin ere, esistentzialista geienai gertatu zaien bezela, gaitz ikusten da, noizpait bedere Camus'ek elburu abstratu bati irmo elduta, baiezte-mallara pasatzea. Bere pentsakera-oñarriak ezagututa zail xamarra dirudi. Oraingoz, ba, abia-bide garbi bat arkitu nai duenak, ez beza irakur. Gaurko giroaren lekuko eta astintzalle da Camus; ez gidari. Gure Unamuno bezela, eragille. (Idem: 68)

Iñaki Bastarrika fedetik mintzo zen, baina Moelleren ildotik, gauza onak aurkitzen zizkion Camusi; Txillardegik, berriz, abiabide garbi bat nahi zuenak Camus bazter zezala zioen - abiabide, hots, Txillardegik berak ere fede garbia aintzakotzat zuen seinale, nire iritzian; bestalde, ez al zuen, ba, Nemesio Etxaniz apaizak ezkondu, 1957ko urte hartan bertan!- . Baina, ñabardura horiek gorabehera, urrun ere ez zeuden elkarrengandik Iñaki Bastarrika eta Txillardegi Camus epaitzean. Nolatan?, zer zela bide izan zuten polemika garratz hura?

Bastarrikak adierazi zuen Txillardegiren existentzialista kutsuko nobela irakurtzeko eta iritzia emateko eskatu ziotela lagunek -Arantzazun, fraidekideek batik bat, uste izatekoa denez-. Irakurri zuen eta honela gelditu zen:

Zer eritzi jakin ez-ta geratu nindukan. Beste oei alako goraipamenak entzunda [Salbatore Mitxelenaz eta Bitoriano Gandiagaz ari ote zen, haiek bakoitzak bere erara txalotu zutenez gero?] oker nengokelakoan geratu nindukan. Dana dala egiari zor gatzaizkiok eta itz-bitan adieraziko dikat nere irizpidea. Egia esan, naste-borraste bat-edo otu zitzaidakekan. Aria ondo eramana. Baiño arrunta xamarra...nere gardiz. (...) Gaiñera, nere ustez behintzat, gai oiek ekarrizkoak baiño areago izan bear ditek etorrizkoak (...) Nortasun egin baten pentsaera umotua baiño esistenzialista joerako nobelari asko irakurritako baten saioak iruditu zaizkidak ire bururapenak. Ez dikat onekin liburu au ire seme ez denik idaroki nai, filosofo-elergille oen kutsapena igan nabarmen somatzen dala baizik, «eragilleena» baitipat. (Bastarrika 1957b: 99-100)

Eta Txillardegiren ihardespena kritika horri:

... ziñez esan dezaket au, nik ez diot iñori zorrik. «Eragilleen» kutsu ori, ezta besteen kutsua, ezta kopiarik, besteakiko topo eta egokiera utsa baizik. Gaurko geran guziok bazter eta paisaje berberak ikusten ditugu-ta. Erdipurdi edo zearo gaizki atera zaidala saioa? Besterik da au. Eta egia baldin bada ere, ezta arritzekoa. Baña sinistuta egon: kopiatu bear izan 
banu, EZ NUKEAN LUMA ARTUKO. Kopiatzalle geiegi izan ditugu euskal literaturan, gaur ni ere alakoai jarrai natzaien. (Txillardegi 1958: 86-87)

Diferentzia zertan zegoen, bada? Ez da erraza argitzen. Bastarrika ez zen fraide kontserbadore itxi bat, baizik eta fraide jakin-minak jotakoa, Frantzian modan zeuden existentzialistak irakurria, Charles Moelleren uberan, haien alde onuragarriak bilatzen saiatua, eta, bai, haiek kristau-fedetik zenbat urruntzen edo zenbat hurbiltzen ziren araberako laudorioak edo gaitzespenak jaurtitzen zituena ere. Eta Txillardegi?, beraren kezka existentzial propioak nobelan isuri zituena, bai, baina aldi berean ez al zen era berean erreparoak eta erreserbak agertzen zituena Camusen negatibotasuna eta transzendentziaren ukapena zela medio, eta Sartreren lohikeriaren aurrean?

Bien arteko eztabaidan, beste puntu garrantzizko bat Euskal Herriko gaien kontuarena zen -idazteko hizkuntza-ereduarena zen beste puntu axola handiko bat orduan, baina hemen ez dugu aztertuko, gaurtik begiratuta axola gutxiago duelakoan-: nobelista euskaldun kostunbrista-folklorista versus nobelista euskaldun unibertsala. Txillardegiren hitzetan:

\begin{abstract}
... au diozu: «Ba-zegok gure errian bertan ikutu-gabeko naiko eleberrigai ederrik asko. Nork bilduko eta eleberrituko zizkiguk?» (...) Zure ustez, oker ez banago, ezpaitzera zu leenengo xinplekeri oietan, euskeraz idazteko «emengo» zerbaitez egin bear da. Zertara joko «kanpora»? (...) Euskaldunok, nere Leturia bezela, gizon gera guziz, baiña euskaldun erara. Gaurko gaztediaren katramillez mintzatzen da nere Leturia, baiñan euskeraz. Presuna unibertsala da Leturia; bere mintzaira, guziarekin ere, gure izkuntza. (...) Egiazko bizian sartu bear dugu euskal literatura. Gure bizimoduari dagokionez, bai; bana presunari ditxezkon auziak azaldu bear ditugu ere. (...) Auxe pentsatu nuen nik nere «Leturia» sortzean. Bestalde, nere liburu au euskeraz izkiriatu ez banu ere, erderaz egingo nukean; eta berdin diot irakurtzen ari zeran gutun onetzaz. Esan BEARRAK eragiten bai nau. (Idem: $87-88$ )
\end{abstract}

Txillardegiren geroko bilakaeraren berri izanda, deigarri gertatzen da hizkuntzari, euskaraz idazteari bigarren mailako garrantzia aitortze hori; axolazkoena nobela engaiatuak idaztea zen, gaurkotasun handikoak eta idazleak bere baitan sentitutako gaiez mamituak, Camusen eta Sartreren lorratzean.

Bastarrika eta Txillardegiren arteko polemika garratz haren azpian ez ote zebilen, muinera etorrita, euskal kultura tradizional erlijiosoaren eta euskal kultura moderno laiko edo laikoagoaren arteko liskarra, bi idazle horiengan haragitua? Praktikan, Iñaki Bastarrika atzerrira joan, eta batez ere Joseba Intxaustik Jakinen zuzendaritza hartzean, Txillardegi erreferentzia bihurtu zen Jakinen ere. 


\section{Txillardegi: Camusengandik Sartregana}

Hil zen auto-istripuz Camus 1960ko urtarrilaren 4an, eta laster plazaratu zuen Txillardegik «Lekuko bikain bat hil da» izenburuko artikulua Eganen (1960). Errepaso ederra emanez haren obrari eta haren eragin zabalari munduan eta gurean ere, bere aitortza eta ezagutza eskaini zizkion, izenburuak berak argi eta klarki adierazten duenez. Hori bai, alde kaltegarria ukatu gabe: «Camus'en alde kaltegarria, alere, iñork eztu ukatu. Eta nik ere ez. Politikarengatik itxaron ba zitezkean iritzi gogorrak, erlijioaren aldetik gogorragoak» (Txillardegi 1960: 52).

Aurrerago aditzera emango dugun bezala, politika aldetik Sartre izan zen Txillardegiren erreferentzia, paristarra PCFtik aldendu zenetik batez ere.

Camusen obraren errepasoa egiteari ekinik, Arrotza nobelatik Izurriara zegoen aldea azpimarratzen zuen, maisuki nire iritzian:

«Izurritea»n urruti gaude «Atzerritarra»tik. Bigarren au irakurrita (...), kutsu arrigarri bat gelditzen zaigu biotzean. Meursault ura, batez ere kondenatua izan arte, eztugu ondo ulertzen: utsean dardaratzen da: gaurko gizon asko bezela, egia da, baiñan alere bere jokaera arrigarri zaigula. Meursault'ek eztu sentitzen, eztu pentsatzen, eztirudi egiazko gizon bat. Bere amodioetan, bere amaren eortzetan, arabitar bat iltzen duenean, ametsetan bezela ari da, ezta ezertaz konturatzen. Geroenean bakarrik, eriotza ondoan ikusi duenean, gizonaren egiazko egoeraz oartzen da; baiñan, orduan ere, leenagoko aroez tristuraz betea oroitzen da. Berak, barne-muiñetan, sasi-biziera ura naiago zuen, sasi-pake ura, sasikeria beraz, egia garratza baiño. «Izurritea»n, berriz, ots, bost urte igarota, Camus ezta leengoa. Eztu Jaungoikoarengan siñisten, jakiña; baiña gizona maite du. Gizonaren patu tristeak sakon unkitzen du eta, biziak salbatu nairik, gogoz lanegiten du izurrite betean. Meursault'engandik Rieux'engana tarte aundia dago, zalantzarik gabe. (...) Camus'en Moralak eztu oiñarria Jainkoa'rengan. Seneka'k eta estoikoak bezela, Moral bat eraiki nai du Camus'ek Jaungoikua gabe. Eta ezta txantxetan ari. «Bizi naizen munduak nazka ematen dit; baiña bertan sufritzen dutenen laguna eta kidea naiz.» Camus'en bizieran zear, biotz onekoa zala nabarmentzen da. Camus egiatia zan, etzan itxura egiteen aldekoa. Bere adiskide guziak ao batez aitortzen dute. Biotzez maite zuen, ba, Camus'ek gizona; zorigaiztokoa aurkitzen zuen. Aurrak, batez ere, bere obra guzietan oiñazearen menpean ikusten dituenean, biotza erdibituta ixuritzen zaio bere errukia. Oran'en, esate baterako, izurritea dagoela jakin danean, mutiko eder bat topatzen du Rieux medikuak. Une labur batez kiñurik egin gabe begiratzen diote alkarri; eta, bapatean, irribarre zabal bat egin dio mutikoak. Orduan, garbi adierazten ausartu ezpadira ere, Cottard'i eta Rieux'i idea berbera gogoratu zaie: «aur zoragarri eta errugabe au, bearbada, izurrite gaisto ontan ilko da. Zergatik bera?»...Errugabeak zigortzen dituen gaitzak beti asaldatzen du Camus, Dostoievsky bezela. (Idem: 54-55) 
Aitortu izan du Txillardegik Leturia interpretatzeko giltza nagusia Camus dela, eta bere garaian ez zela nobelaren sinbolismoa ulertu:

Nire nahian bederen, denak dauka bere funtsa (Camus-en La Peste-k izan bide zuen honetan eragin nagusia): «uda» garaian Leturiak ezer ez idazteak, argi arrazionalaren bila Parisera egindako bidaiak, denak. Ustez, bederen, denari datxekio bigarren mailako irakurketa. Irakurlerik gehienek ez zuten sinbolismoaren gakoa somatu, eta honek dexente sufriarazi ninduen. Autore guztion ezinak, nik uste. (Txillardegi 1994: 143)

Moralaren aldetik, Camus kristau bihurtu zen pixkanaka. Eta moralaren kezka hori gero eta biziagoa zuelako katoliko askok bere alde hitz egiten zuten; eta, bestetik, Jainkoa ukatzen zuelako, aurka beste batzuek, bere filosofia kondenaturik. Batzuen eta besteen iritzi kontrajarriak gorabehera, honako bi ezaugarri hauek zituen alde: egiazkotasuna eta jatortasuna. Eta konklusio modura:

Camus'engan, nik beintzat, gizon aparta bat aurkitu uste dut leenik. Gizon bat: ezagutu nauen gizon bat, gure aldiko lekukorik bikainenetako bat. Ez, gaiñera, Fontán'ek eta bestek diotenez, geure aroko lekuko bat. Nik eztut ori uste. Gizonaren heiña, larrimiña eta gogoa, orren errotik ezagu-erazi dituen idazle bat, illezkorra da, eta ezta sekula guzian aaztuko. Beraz, bijoakio Camus gizonari nere errespetu-itzal guzia. Danok zor diogula uste dut. Eta, Unamuno'k bezela, soluzioa emateko Camus'ek balio ezpadu, bizierak bear duen sentiduaren egarria pizteko, leengo mallakoa dala deritzat. (Txillardegi 1958: 58)

Gizon aparta. Unamunoren pare, bizitzaren zentzuaren egarria pizteko lehenengo mailakoa!

Eta, Sartre? Lehenbiziko aldiz, oker ez banago, Zeruko Argian idatzi zuen (1964an), hark Nobel Sariari uko egitean. Hura hiltzean idatzi zuen Punto y hora de Euskal Herrian (1980); berriz, 1987an kazeta berean, eta Euskal Herria helburu (1994) eta Horretaz (2007) liburuetan. Azken honetan, Camus eta Sartrez, honela zioen:

Camusekiko harremanak (4) aztertzeko asmoa banuen. Baina urrutira eramango ninduke, eta saiakera bilduma honetan lekurik ez. Agian beste batean! Oso zelebrea da egoera funtsean. Camus aljeriarra, "Aljeriako frantsesa $»^{2}$ esan ohi zuen harro, uzkur agertzen da herri kolonizatuen arazoaz. Beti prest kolonizatuen jokabidea kritikatzeko, eta Frantziarena nola-hala onesteko. Sartre paristarra, aldiz, prestago dago beti kolonizatzailea gaitzetsi eta kolonizatua konprenitzeko. Eskuin/ezker joera sakona suma daiteke aise dikotomia horretan. (Txillardegi 2007: 21)

\footnotetext{
${ }^{2}$ Frantsesez zegoen barne-aipua neronek itzuli dut. Hauxe jatorrizkoa: «français d'Algérie».
} 
Hor ikusten da politikoki Sartre ezkertiarra gehiago estimatu izan zuela Camus baino. Horretan duda izpirik ez dago, baina era berean gogoratu beharra dago Camus 1960an hil zela, eta Sartre 1980an, eta bereziki Sartrek Aljeriako gerrakoan, eta Vietnamekoan (Russell auzitegia), eta 1968tik aurrera ETAren eta Espainiako gobernuaren artekoan, Burgoseko auzia zela medio Gisele Halimiren liburuarentzat idatzitako hitzaurre famatuak-eta zerikusia izan zutela Sartreren eragina eta miresmena hazteko Txillardegiren baitan, eta Camus ahaztura bidean, edo atzerago paratzeko.

Sartrek Nobel Sariari uko egitean idatzitako artikuluan, literatura eta filosofia aldetik ere aldezten zuen:

Sartre'k ez du Jainkoagan siñisten. Ez du Jainkoa aipatu ere egiten (eta huntan ez da biziki bitxia, ez pentsa). Eta, bestetik, filosofiaren aldetik, etsistentzialismoaren ezagugarriak ditu: ikusi gabe behar du gizonak hautatu; gizonaren sentidua ezin dezake adimenduak ezertan argi; Ezerezak inguratzen gaitu alde guzietatik; heriotzarat ari gera; eta abar. Beltza da Sartre, ukatzaille da, Kierkegaard bezela, Unamuno, Heidegger, eta gaiñerako etsistentzialista guziak bezela. Hutsean dardaratzen baldin bada gizona, Sartre'ren Literatura-norki edo pertsonajeak ez dira bere filosofiaren nahi-ta-nahiezko ondorea baizik. Sartre'ren etsistentzialismoa da, horrela, Sartre'ren kakoa (...) Bai, irakurle. Etsistentzialismo-motak oro, funtsean harturik, (ez beraz Sartre'ren erakoa bakarrik) gizonaren kezka nagusiaren ume dira; eta ezin ditezke huskeriatzat edo modañotzat har. Sartre, alde huntatik, munta haundiko filosofo bat iruditzen zait; eta literaturako bere lana, filosofia horren erakusle eta argitzaille dan aldetik hain zuzen, oso inportantea ere. (Txillardegi 1985 [1964]: 89-90)

Eta, politikoki, zer esanik ez.

... politikaren maillako bere jokabideek azal dezateke, ongienik nik uste, Sartre'ren kontrako gorroto amorratua: Sartre ezkertarra baita politikaz. Ez komunista. Komunista izateko marxista izan behar da; eta marxistaz gain, leninista; eta leninistaz gain, stalinista, krutxefista, brexnefista, eta abar, aldikal. Bistan da, ordea, «L'Etre et le Néant» eta «Le Capital» bi mundu dirala. Sartre ez da nehundik ere komunista. Baiña sozialismoaren aldeko da, eta kapitalismoaren etsai: hau bai. Nobel-Sariari uko egitean, ez du bere ezkertar joera hori izkutatu: «Nire sinpatiak, ezbairik gabe, sozialismorantz doaz, eta Ekialdeko bloke deritzogunera». ${ }^{3}$ Bere iritzia hori da; eta iritziak libro dira. Bestetik, bere ideia horien arabera jokatuz, «intelektual» izena merezi izan du berriz. Ezen ideien arabera jokatzeak merezi baitu txalo; eta are gehiago merezi, hogei ta zazpi

\footnotetext{
3 Txillardegiren aipuan frantsesez emana zegoen barne-aipu hau neronek itzuli dut. Hemen jatorrizkoa:
}

«Mes sympathies vont indéniablemente au socialisme, et à ce qu'on appelle le bloc de l'Est.» 
milloi liberaren galera dakarrenean. Ez dut ikusten, beraz, bere ukoan, ezer ere arbuiagarririk. Ukoa ohore zaiola uste dut. Sartre beti jokatu da aitziñakoi edo progresista guzien alde, eta kolonialismoaren kontra. Bertrand Russell ere berdin. Ez dut hortan akatsik ikusten. (Idem: 90)

Hitz horiek oso ongi laburbiltzen dute Sartrek Txillardegirengan izan zuen eragina, hots, nolako erreferentzia izan zen berarentzat -Bertrand Russellekin batera-. Artikuluaren amaieran zioen ezkertiarren eta eskuindarren marra nondik igarotzen zen garbi utzi zuela afera hark.

Hil zenean idatzitako artikuluan, «Sartre: lekuko eta gidaria» deritzanean (1980), 30 urtez gidari aparta izana zela aitorturik - Hungariako sobietarren inbasioan, Tito eta Castroren politiketan, Aljeriako gerran, Israel eta Palestinaren artekoan, eta 1968ko Burgoseko prozesuarenean-, honela zioen:

Totalitarismo mota guztien salatzaile, nazio zapaldu guztien defendatzaile gartsu eta etengabea, zordun zaizkio Sartreri zapaldutako guztiak: bai klaseak, bai herriak. Eta ez da harritzekoa, horretara Memmi-k eta Sartre-k, azkeneko asteetan egin dituzten deklarazioetan, ia-ia hitz berberez mintzatzea zapaldutako eta baztertutako giza-taldeei buruz. Klase-anaitasunaren gainetik, Sartreren ustez, herrikidetasunak ematen duen anaitasuna dago («fraternité» dio Sartrek). Hona zer zioen hitzez hitz; «Gizonen harreman sakonena ez da ekoizpen harremana... lehen harremana senidetasunarena da. Harreman hori ez da mito bat: senidetasuna espezieak bere kideen artean duen harremana da. Duela milaka urte, lehen zatiketa soziala klanarena zen, bere totemak ezaugarritua. Horretxek biltzen zuen klan guztia, eta klaneko kide guztiei errealitate sakon bat ematen zien... eta harreman hori senidetasunarena zen». Horra hor «clan» eta oinarrizko anaitasun horren aldeko hitzak hil baino lehenago. Berriak al dira, egia esan, Sartre-rengan? Ez, nik uste: «euskal herri bat badago eta bretoi herria ere, baina jakobinismoak eta industrializazioak hil dute gure populua: ez dago, gaur egun, masa frantsesa besterik» (Le Procés de Burgos, Sartre, 1971). Galtzaira handia, beraz, Sartre-rena. Denontzat hori. Baina galtzaira handia batez ere euskal ezkertar abertzaletasunaren ereintzan eta moldakuntzan ari garenontzat. Baldinba ugalduko dira Sartre-ren euskal irakurleak! Agian bai, mila aldiz! ${ }^{4}$ (Txillardegi 1980: 18-20)

4 Txillardegiren aipuan frantsesez emanak zeuden barne-aipuak neronek itzuli ditut. Hemen jatorrizkoak:

«Le rapport le plus profond des hommes n'est pas le rapport de production... le premier raport est le rapport de fraternité. Il ne s'agit pas d'un mythe: la fraternité c'est le rapport de l'espèce entre ses membres. Il y a des milliers d'années, la primière division sociale c'était le clan, caracterisé par son totem. C'etait quelque chose qui enveloppait tout le clan, et qui donnait a tous les membres du clan une réalité profonde... et ce rapport là c'était un rapport de fraternité.»

«il y a un peuple basque et un peuple breton, mais le jacobinisme et l'industrialisation ont liquidé notre peuple: il n'y a plus, aujourd'hui, que des masses françaises.» 
Sartre jaio zela ehun urte betetzean (2005ean), berriz heldu zion bere bizitzan erreferentzia izan zuenari, eta, orduan idatzitakotik, idazle konprometituari eskainitako atala da adierazgarriena, zeren Txillardegi idazle engaiatua izatera batik bat Sartrek bultzatu zuen:

Alegia: besterentzat idatzi behar dugula aldarrikatzen zuen Sartrek; inguruan eragiteko tresna zela luma. Eta honek bizkortu egin ninduen neure xedeetan. «Abiatu aurretik hautua egin behar du idazleak: ea pinpilinpausez idatziko duen, ala juduen patuaz» (Sartre-ren jarrera ulertzeko, nazien genozidioa gertatu berria zela hartu behar da kontuan, eta Israel jaio gabe zegoela). (...) «Idazlea bere garaikideei mintzo zaie, bere aberkideei, bere arrazakide edo klasekideei». Ideia horiek entzutean, jarraitzaileek galdera hau egiten zioten Sartreri: «Zein mugimendutan edo taldetan egin behar du lan idazle konprometituak?». Erantzuna eufemismorik gabe eman ohi zuen filosofoak: «Gaur egun galdera hori egiten baldin bazait, populuaganaino («les masses» zioen berak) iristeko bere zerbitzuak Alderdi Komunistari eskaini behar ote dizkion, nik ezetz erantzuten dut: komunismo estalindarra, batetik, eta literaturagintza prestuki moldatzea, bestetik, ezkondu ezinezkoak dira». (...) Zalantzarik gabe, iraultza sozialistarako bidea PCaren ezkerretik bilatzen zutenek interes handiz irakurtzen zituzten izkribu hauek. Nik ere bai. Deplauki aitor dizuet. (Txillardegi 2007: 23-26)

Gaur egun ez daude boladan idazle konprometituak; halere, gutxi izanagatik, beti dute eragina. Eta horixe da Txillardegiren aholkua: izan zaitez idazle engaiatua, Sartre eta Txillardegi bera ere izan ziren bezala!

\section{Emilio Lopez Adan Beltza}

Euskal idazleen artean, oker ez banago, Emilio Lopez Adan Beltza izan da aurrena Sartre eta Camus gisa horretan, paristarra iraultzarekin lotuz eta Camus erreboltarekin, bata bestearen aurka paratu dituena. Txillardegik ere hein batean jarri zituen elkarren aurka, esaterako, Aljeriako gerrakoan, Sartreren alde eginez, baina ez Lopez Adanen gisa berean. Artikulua 1980koa da, eta, jakina, data jakitea axola handikoa da. Urte hartan jazo ziren politikaren ondoriozko hilketa gehien Euskal Herrian: 94 (ETA militarrak egindakoak 79, Komando Autonomoek 10, eta ETA pm-k 5).

Honela laburtzen du Lopez Adanek Camusen teoria:

Zapaldurik bizi den pertsona, menperatzen duen sistemaren kontra altxa daiteke eta, beste pertsonekiko elkartasunak higiturik, besteekin bilduz, ororen mogimendua errebolta bihur daiteke; halere, ideologia batek, historia osoa esplikatu eta nagusitu nahi duen ideologia batek, erreboltarien eginkizuna dominatzen eta zuzentzen duenean, menperatzaile bilakatuko da errebolta bera, bere kontra dauden ororen gainean laztura eta heriotza erabiltzen dituelarik. (Lopez Adan 2012: 23) 
Bere teoria frogatzeko adibide historikoak erabiltzen zituen eta horietan nagusia Errusiako Iraultzarena zen. Han bidegabekeriaren aurka hasitako errebolta jatorra marxismoak hondarazi zuen eta, Camusen iritzian, estalinismoa zen ideologia absolutu haren ondorengo zilegia. Marx eta Lenin ziren Stalinen aintzindariak, eta injustiziaren kontrako errebolta Estatuaren terrorismo huts bihurtu zenean ez zen halabeharrez izan, baizik eta marxismoaren barne-logikagatik.

\section{Camusek zioenez:}

Hemen hil zen, betirako, askatasuna. Masen erresumatik, iraultza proletarioaren noziotik, profesionalek egindako eta zuzendutako iraultza baten ideiara pasatzen da. Estatuari buruz lehen egiten zen gupidagabeko kritika adosten da, gero, proletalgoaren diktadurarekin, hau da, diktadura beharrezkoa baina, noski, probisionala, zuzendarien pertsonetan gihartua. Eta, azkenean, probisional honen bukaera inork ez daki noiz izango den, eta inork ez du bukaera izango denik agindu nahi. Horrela, dena logikoa da: Sovieten autonomia pikutara, Makhno salduta, Kronstadt-eko marinelak garbituak (G.E., 285-286 or.). (Lopez Adan 2012: 24)

Francis Jeansonek, lehenik, eta Sartrek, haren ondotik, Camusen planteamenduari egindako kritikak jaso eta haiek nolabait uztartzeko eta adosteko aterabide hau aurkitzen zuen Lopez Adanek:

Errebolta eta iraultza bi esparru ezberdinetan kokatzen dira. Errebolta portaera da, iraultza gertakizun historikoa. Erreboltak sistemaren aurka ihardutea exijitzen du; iraultza bilakabidea da, bere aintzina eta bere geroarekin. Iraultzaren bilakabidean, etengabeki ari da errebolta, eta erreboltariek egiten dute iraultza. Semantika honetan, praktika honetan ere bai, erreboltari kontrajar dakiokeena konformismoa dugu, edozein garaitako konformismoa, nahiz iraultzaren aintzineko sistema onartzen duena, nahiz iraultzaren bilakabidean urrats partzialak definitibotzat jotzen dituena. Horrela, erreboltari izan gaberik ezin egin daiteke iraultzarik. Baina edozein erreboltak ezin lezake iraultza egin. Duda gaberik, pertsonari bere duintasuna ematen dion sendimendua erreboltarena da: edozein injustiziaren aurkako higuina, sistema menperatzailea hausteko nahikaria, hona hemen errebolta honen osagaiak. Baina sendimendu honek ezin ihardun dezake soilki baloreen mundu abstraktuan: historiko bihurtu behar du, egikorra izan dadin. Ingurune historikoa ulertuz konpreni daiteke nondik jo behar duen gure haserreak mundua aldatzeko; eta gaurregun klase borroka eta Estatuaren eginkizuna kontutan hartu gaberik ez dago ulerkera onik. Halere, ezagutza ideologia bihur daiteke. Ideologiak, noski, prozesu historikoaren ikuspegi orokorra ematen $\mathrm{du}$, baina ideologia sortu duen taldearen ikusmoldea ematen du eta azken funtsean talde honen egoera eta pribilegio estatikoak defendatzen ditu. Eta iraultza proletarioan ideologiak ez dira faltatzen: burokra- 
tena, iraultzaile profesionalena dugu bat. Leninismoak dio proletalgoa ez dela berez iraultza egiteko gauza; talde profesional batek eman behar dio iraultza egiteko gaitasuna. (...) Alderdi hauek boterea hartu duten lekuetan, herriaren gaineko diktadura, Estatuaren terrorismoa, gauza ezagunak dira. Ez da erraza, teoria hutsean bederen, minoriaren diktadura justifikatzen duen ideologia hau «egiazko marxismoaren» parte bat dela esatea, edo, alderantziz, marxismoaren sasikume bat; baina alderdiaren kontrola hartzen duen burokraten ideologia dela nabaria da, eta marxismoari hobena ez badiogu leporatu nahi, onartu beharko genuke, halere, boterearen irrikak, gurariak, indar aski duela marxismoa bera endekarazteko. (Lopez Adan 2012: 25)

Camusen funtsezko hautua 1980ko egoerari egokiturik, honela azaltzen zuen Lopez Adanek:

Bi biolentzi mota bereiz genitzake. Lehena, bitartegabeko erantzunari dagokio: zapaldurik, umildurik, gogaiturik dagoenak bere aintzinean ikusten du etsaia, aurrez aurre, zigorra eskuetan eta berriz jotzeko prest, eta etsaia garbitzen du; edota anaia zitalki hil duen borreroaren bila abiatzen duenarena, gauez, mendekuaren su itzalezinak eramanarena... Bitartegabeko biolentziak ez du justifikazio iraultzailerik behar: horrela gertatzen da, horrela da. Menperatzaile zuzen eta ezagunen aurka egiten da, eta erreboltaren atala dugu. Baina beste biolentzia bat dago: hozki erabakitzen dena, estrategia baten barnean sartzen dena, alegia; etsaiak nortzu diren erabaki eta gero, ingurune historikoaren baldintzak eta barne indarrak arakatu eta gero, egiten dena. Batzuek, sistemaren morroiak banan banan garbitzea erabaki dezakete, sistema hori, agian, ahultzeko; besteek, berriz, iraultzaren etsai objetiboak beren partiduaren estrategiaren aurka daudenak direla lasaiki erabakitzen dute, eta salaketak, gezurrak edo erdiegiak erabiltzen dituzte, sistemak berak, edo uste publikoak, edo inkontrolatuek, «etsai objetibo» horiek zigor eta deusezta ditzaten. Eta hemen datorkigu zalantza: gure ideologiaz, gure estrategiaz, gure alderdiaz, honenbeste fida al gaitezke besteen heriotza justifikatzeko? Iraultzaren historian, edo gure herriko historia xumean, estrategiaz ez al da behin baino gehiagotan aldatu, estrategia bati ezin eman dakiokeela balore absoluturik garbi ikus dezagun? Haustearen alde zirenak ez al dira gaur paktuaren alde, atzoko iraultzaileak terroristak bezala salatzen dituztelarik eta atzoko indar errepresiboak gaur langile zintzo bezala onartuz? Eta errepresioarekin zer ikusirik ez duten pertsonak hiltzen dituztenean (geltoki batetan edo taberna batetan), gure talde armatuek ez al dute doako hilketa egiten, autokritika batek edo herriari azalpen batek ezin konpon dezakeen hoben gaitza? Horrela egitekotan, errepresioaren eta zanpaketaren erresponsable zuzenak ez direnen heriotzak erabakitzerakoan edo arinki onartzerakoan, sentimendu iraultzailea ez al da formula huts bihurtzen, erailketa justifikatzen duen formula madarikatua? Zapaltzaileen sistema hausteko eraginkortasuna eta erreboltaren etika uztartzerik balego, hori bitartegabeko biolentziaren kasuan izango litzateke posible. (Lopez Adan 2012: 27-28) 
Halere, intelektualki Camus eraberrituari jarraiki arazoari soluziobide teorikoa aurkitu uste arren, praktikan hori gauzatzea ezinezko epaitzen zuen 1980an:

Halere, non dago bi biolentzien artego muga? Biolentziaren eginkizun historikoan sinesten dutenak, beren bizitza propioaren sakrifizioaz indarturik daudenak, onar al dezakete ideologiaren jopu eta jostailu itsu izan litezkeela? Ez, ez dute zalantza onartuko: eta horrela iraultzaren historiak bere barne tragediaren historia lazgarria izaten jarraituko du. (Lopez Adan 2012: 29)

\section{Joxe Azurmendi}

1998an argitaraturiko Oraingo gazte eroak liburuan —Lizarra-Garazi garaian argitaratua, pixka bat lehenago idatzia-, Camusi gorazarre egin zion zegamarrak — Sartreri ere bai, baina bereziki Camusi-, aditzera emanez guztien maisu handi bat izan zela 50eko hamarkadan.

Liburu horren oinarrian, Nemesio Etxaniz eta Andima Ibinagabeitiaren gutunak daude; eta horietan, besteak beste, Etxanizen eta Ibinagabitiaren itolarria eta larrimina sumatzen da, bereziki Etxanizena: 1936ko gerran Elizaren hierarkiak harturiko bidea ezin onetsi, morala frankista izatea ezin eraman inola ere, eta bizitzan apaizgoa hautaturik hautu desegokia egin izanaren kontzientzia ezin kendurik gainetik. Beraientzat, 50eko hamarkadan idazkuntzari ekin ziotenentzat, desenkantu horretatik ateratzeko Camus zein garrantzizkoa eta zein eskergarri gertatu zen azaltzen du Azurmendik, 50eko urte hits haietan «liberazioa» izateraino.

Garai hartako izpirituaren espresio bat hartzekotan, bada —hezi eta eratu gaituena, guretzat «liberazio» bat signifikatuz-, Camus hori hauta liteke. (Sartre edo beste asko ezertan gutxietsi gabe-Unamuno bera ere!). Camus ez omen da benetan filosofoa. Berdin da. Filosofoa historiarentzat edo akademientzat zer den utzita, filosofoa guretzat ez da gauzak pentsatu dizkiguna, pentsarazten dizkiguna baizik. Planteatzera obligatzen gaituena. Eta Camus, «solidaritasunaren lekukoa», bere nobelekin eta teatroarekin, saioekin, bere aureolarekin (Nobel Sari gaztea, Erresistentziako kazetaria, Algeriako gerran kritikoa, kritikoa beti Estatuarekin eta Elizarekin, etab.), bere pentsamendu egiati moralarekin, «libertinoa» nolabait aldi berean, azkenean bere heriotza tragikoarekin ere istripu «absurdu» batean (1960ko urtarrilean), kontzientzia maisu miretsi eta maitatu bat izan zen gerraondoko gazteriarentzat. (...) gizatasun paregabea goratuz, ideologien eta Alderdien gainetik beti «gizonaren eskubideen alde» (Arestik berea egin eta gogotik erabiliko duen espresioa zen hau; eta ez da esamolde batere marxista). ( ) Camusen obran, etxean eztabaidatzerik ez zegoen ideia guztiak aurkitzen ziren, misterio gabe lasai-lasai azaldu eta jorratuta: frankismoaren kritikarekin, komunismoa- 
ren kritikarekin, demokraziaren kritikarekin, dena libertate freskoenez. (...) Demokrazia, iraultza, bortxa: gaintxuriturik gabe eta santukeria gabe erabiltzen ziren problema guztiak, eta ez zen ematen eskolako soluzio bat, arazo bakoitzaren errezeta modura, baina izpiritu bat irakasten zen orohar eta bizitzaren filosofia bat — «inolako metafisikarik gabe, inolako sineskerarik» nahasteke: doktrinarismoaren arrastorik ez! — arlo guztietan bakoitzak nola ibili jakiteko. Soluzioa ez dakigu. Dakigun bakarra da, zein izpiriturekin beti jokatu. (Azurmendi 1998: 35)

Bere belaunaldiaz mintzo, dio ahalegin handia egin behar izan zutela egiazko historia —ezkutatua, ukatua-, Euskal Herriaren historia bizia -hots, hizkuntza, literatura, zuzenbidea eta tradizio politikoak, kultura guztia- deskubritu eta ikasteko, eta aldi berean hori dena transmiti ziezaiekeen kultura (esanahi txarrenean) «tradizionalista» gainditzeko:

Orixe («Euskaldunak»), Txomin Agirre («Garoa»), etab., politikoki ez dira izan abertzaleak, kulturalki tradizionalistak bai. Horregatik abertzaletasun tradizionalak problemarik gabe baitaratu ahal izan ditu. San Martinek edo Txillardegik, ostera, anakronikoak eta kasik beren euskal kontzientzia berriaren iraingarritzat sentitu dituzte. (Uste dut, halere, birresatea ez dela sobera egongo, etena, belaunaldi berriak, berak egin baino areago, nozitu egin duela. Euskal historiatik apenas ezagutzen genuen, ezta gerra zibilekoa ere: iraganik gabekoak jaio ginen!). Gazteok beste era batera ikusten zuten iraganaren arazoa; gure iragana, Europan guztien iragan bera zela, sumatzen zuten: Voltaire eta Marx, Unamuno, Kierkegaard... (Aizpuru 2016: 127-128)

Eta kultura zahar tradizionalista horretatik ihesi, europar kulturaren bila, existentzialismoak -Espainian debekatua zenez, erakargarriago izateko arrazoi bat gehiago! - mintzaira bat eskaintzen zien, paradigma bat, erlijioarekin eta politikarekin hausteko eta jauzi baten mundu berri baten paratzeko. Horretarako, Sartreren adreilu filosofiko ulergaitzak baino testu egokiagoa $E l$ existencialismo es un humanismo (1984 [1946]) laburra gertatu bide zitzaien:

«Gizakia, existentzialistak bururatzen duen bezala, ezin defini badaiteke da deus ez izatetik hasten delako. Bakarrik gero izango da, eta bere burua egin duen bezala izango da. Hala, bada, ez dago giza izaerarik, ez baitago Jainkorik hura burura dezakeenik. Gizakia da bakarra berak bere burua bururatzen duen bezalakoa dena ez ezik, berak bere burua izan dadin nahi duen bezalakoa dena, existentziarako bulkada horren ondotik bere burua izan nahi duen bezalakoa; gizakia berak bere burua egiten duena baino ez da. (...) Jainkorik ez bada, gure aurrean ez ditugu balioak, zuribideak edo aitzakiak aurkitzen. (...) Bakarrik gaude, aitzakiarik gabe. (...) Pentsatzen du, bada, gizakia, inolako sostengu eta sorospenik gabe, kondenatua dagoela une oro gizakia asmatzera». Itsasoan galdurik gabiltza hortaz eta zeruan ez da gida gaitzakeen izarrik: guztientzat eta beti baliozko moralik inon ez dago jada. «Ezein moral orokorrek ezin 
digu esan zer egin behar dugun; ez dago zeinurik munduan. Katolikoek esango dute: bai, zeinuak badaude. Onar dezagun: neu naiz haiek zein zentzu duten aukeratzen duena». ${ }^{5}$ (Eta, orain, galderetan galdera: biolentzia «bidezkoa» da?). (Izagirre 2000: 131-133)

Galdera horri beste artikulu baten bidez erantzun dio, hain zuzen bortxaren bidezkotasunaz Parisen II. Mundu Gerraren ondotik egindako hausnarketa mugarria berreraikirik. Testuingurua, orduko hartan, komunistek Iraultza egiteko zuten asmoarena zen. Errusian arrakasta izandakoak, zergatik ez zuen arrakasta izan behar Frantzian? PCF alderdi komunista frantsesak 800.000 afiliatu zituen 1946an. Sobietarrek naziak menderatu berri zituzten, eta komunismoaren indarra eta prestigioa gaur egun baino mila aldiz handiagoak ziren. Horrenbestez, zilegi zen bortxa (atentatuak, eta abar) erabiltzea Iraultza egiteko? Nazien aurka zilegi baziren makisa, atentatuak, hilketa indibidualak, trena errailetik irteteak, zergatik ez sistema kapitalistaren egiturazko bortxaren aurka ere? Merleau-Pontyk sutu zuen polemika Humanisme et terreur (1947, Humanismoa eta izua) saio-bildumarekin. Segidan etorri ziren Simone de Beauvoirren Pour une morale de l'ambiguité (1947, Anbiguotasunaren moral bategatik), Sartreren Les mains sales (1948, Eskuak zikin) eta Le Diable et le Bon Dieu (1951, Deabrua eta Jainko Ona), eta Camusen Les justes (1949, Justuak), eta L'Homme révolté (1951, Gizon matxinatua). Eta, 1952an, Sartre eta Camusen arteko polemika garratza, ordura arte adiskideak izandakoak betiko banatu zituena.

Merleau-Pontyk moral burgesaren terrorearen eta humanismoaren arteko oposizio sinplista ukatu du: aitzitik, terrorea ei da humanismo egiazkorako bidea; kapitalaren bortxaren petik askabide bakarra. Erabakigarria zera da: bortxaren zilegitasunaren arazoa Merleau-Pontyk ikusmolde moral eta biografiko indibidualetik historikora eraman dizula. Eta historia bortxaren espazioa da: «Historia terrorea da». Kontua ez da bor-

\footnotetext{
${ }^{5}$ Izagirreren aipuan gaztelaniaz emanak zeuden barne-aipuak neronek itzuli ditut. Hemen jatorrizkoak:
}

«El hombre, tal como lo concibe el existencialista, si no es definible, es porque empieza por no ser nada. Sólo será después, y será tal como se haya hecho. Así, pues, no hay naturaleza humana, porque no hay Dios para concebirla. El hombre es el único que no sólo es tal como él se concibe, sino tal como él se quiere, y como se concibe después de la existencia, como se quiere después de este impulso hacia la existencia; el hombre no es otra cosa que lo que él se hace. (...) Si Dios no existe, no encontramos frente a nosotros valores, justificaciones o excusas. Estamos solos, sin excusas. (...) Piensa, pues, que el hombre, sin ningún apoyo ni socorro, está condenado a cada instante a inventar al hombre.»

«Ninguna moral general puede indicar lo que hay que hacer; no hay signos en el mundo. Los católicos dirán: sí, hay signos. Admitámoslo: soy yo mismo el que elige el sentido que tienen.» 
txarik onetsi nahi dugun ala ez, zein bortxa hobetsi nahi dugun baizik. «Ez dugu aukerarik purutasunaren eta biolentziaren artean, biolentzia mota desberdinen artean baizik». Pentsa genezake, moralaren izeneanedo, guk bortxari uko egin diezaiokegula. Baina bortxak berean jarraituko du munduan. ${ }^{6}$ (Azurmendi 2011: 95-96)

Sartreri inpaktu handia eragin zion Merleau-Pontyren testu horrek, berak adierazi zuenez. Baina historiaren interpretazio marxista beraren existentzialismoarekin osatu beharra zegoela pentsatu zuen:

Sartrerentzat bezala Camusentzat ere historia bortxa da, eta bortxa drama. Baina Camusek bortxaren esplikazioan elementu ideologiko edo historiaren filosofia oro baztertu eta subjektuaren drama bakarrik uzten du. Camusen planteamendua etiko-estetikoa da. Historian ez, baina gizakian zentratzen da bera. (...) Camusentzat, berriro humanizatzeko, pentsamendu historizistari uko egin behar diogu. Gizaki garaikidearen gaitz esentziala — gaitz alemana deritzo berak horri!- historizismoa da, eta, bereziki, gizakiaren hybris edo mozkorra historia dominatzeko eta horren nagusi bera jartzeko. Gizaki moderno ipartarrak Jainkoa uzkaili eta gizakia dibinizatu du, bitartekorik bortxazkoenak justifikatuz bera munduaren jainkotzeko. (...) Historia dominatu nahita masakrerik handienak egiten dira, eta justifikatu egiten da hori. Camusentzat, aldiz, edozein hilketa eskandalu intelektual eta moral bat da. (...) Bortxa saihestezina da eta zuriezina da. Sisifok orain egin dezakeen guztia da bere patua onartu eta madarikatu; ez heroizatu eta sublimatu. (Azurmendi 2011: 97)

Les Temps Moderneseko taldean denak ados ziren Camus gogor kritikatzean. Camus mindu egin zen, eta Jeansonen artikuluaren atzean Sartre zegoela pentsatuz, Sartreri kritika zakarra egin zion aditzera emanez, besteak beste, komunisten aldeko ezkertiarrak 1940ko nazien aldeko kolaboratzaileen berdinak zirela politikoki eta moralki. Azurmendirentzat, Sartrek Camusi egindako kritika garrantzizko bat honako hau izan zen:

... moralaren izenean hasi eta inmoralitatean bukatzen duela; moraltasun indibiduala salbatu nahiz inmoralitate soziala onartzen da. «Zure morala lehenik moralismo bilakatu zen, egun literatura baino ez da, eta bihar menturaz moraltasunik eza izango da». ${ }^{7}$ Betiko kuestioa: zapal-

${ }^{6}$ Azurmendiren aipuan frantsesez emanak zeuden barne-aipuak neronek itzuli ditut. Hemen jatorrizkoak:

«L'Histoire est terreur.»

«Nous n'avons pas le choix entre la pureté et la violence, mais entre différentes sortes de violences.»

7 «Votre morale s'est d'abord changée en moralisme, aujourd'hui n'est plus que littérature, demain elle sera peut-être immoralité». 
kuntza egoera batean, bortxa ala bortxaeza da inmorala? Zer balio moral dauka protesta baino ez den bortxak; edo bortxari a priori edozein helburu positibo ukatzean zer moraltasun datza? Ala moralitatea goraipatzea inmoralitatea ezkutatzeko da (erantzukizunik asumitu nahi ez izatea)? (...) Kritika honi Camusen inkoherentziarena gehitzen zaio: moral tradizionalaren kritika bezala hasi, eta, itzulinguruka, berriro moral hartaraxe itzultzen dela, beste erretorika batekin. Hots, egiten dituen absolutu ororen (erlijiosoak, historizistak) kritika indartsuak, inola kuestionatu gabeko balio transhistoriko absolutuen baiespenetik egiten dituela (Egia, Justizia, Solidaritatea, Askatasuna); transzendenteak eta absolutuak metafisika platonikoan eta judu-kristauan direnak hain zuzen. Camusentzat Jainkoa ez da hil. Camus ez da ateista —ironizatzen du Jeansonek-; antiteista pasiboa da. (Azurmendi 2011: 99-100)

Bortxaren bidezkotasunaz idatzitako artikuluari, Sartre eta Camus berariaz aipaturik, konklusio honekin ematen dio buru:

Gerra osteko gizartean bortxaren (Erresistentziaren!) legitimazioaren arazoa, ez dut esango behar adina eta bezala gogoetatu denik, baina bai beti kezka izan dela. Beharbada kontsolagarria, Sartre bezainbat Camus, biak ala biak, hemen eman zaien tratamendu laburretik haratago, soluzio baten bila haztamuka ikustea da euren eboluzioan, ez soluzioaren jabe seguru. Ez dira erlijiosoki dogmatikoak à la Gandhi. Egon ere, bortxarekiko behar dugun morala, egiteko dago, eta egiteko egongo da beti, horrentzat ez dagoelako hamar agindu eternalik harrizko taulan: erantzuna gizarte bakoitzak eta aro bakoitzak beretzat erabaki — hautatubeharrekoa delako. (Azurmendi 2011: 101-102)

\section{Ideia nagusien laburbilduma}

Filosofia existentzialaren eraginaren bitartez, euskal idazle erreferentzial batzuek hausnartu zuten euskal ikuspegi erlijioso tradizionala zalantzan jartzea, eta, II. Mundu Gerraren ondotik, iraultza komunista aurrera eramateko biolentzia erabiltzearen zilegitasunari buruzko polemikatik —nazismoaren aurka zilegi bazen, kapitalismoaren aurka zergatik ez?-, Francoren erregimen faxista, eta gero haren erreforma, borroka armatuaren bidez zalantzan jartzea bidezkoa ote zen.

Camusek eta Sartrek filosofia existentzialistaren gorabeherekin, 36ko gerraurreko eta gerraondoko euskal idazle adierazgarri batzuengan izandako eragina eman dugu aditzera labur-zurrean; nola bi autore frantses horien ideiek bitan edo hainbat zatitan partitu zuten euskal intelligentsia erlijiosoa - gehiengoa zena alde handiz - eta laikoa, baina era bertsuan hezkuntza erlijiosokoa, eta pentsamendu modernoaren ernamuin gertatu ziren gurean. 
Orixek eta Erkiagak eta Zaitegik-eta jarraitu zuten sinesmen sendoarekin, eta mespretxuz ere hartu zuten hasiera batean existentzialismoa, 50eko hamarkadako lehen urteetan, baina Txillardegik, Leturia argitaratzean, lurrikara ideologikoa edo posizioak birpentsatzea eragin zuen, Arantzazuko frantziskotarren artean. Iñaki Bastarrika eta Aita Villasante, funtsean, gogoeta existentzialisten aurka posizionatu ziren, nahiz Txillardegiren nobelagintzari alde onak ere aurkitu zizkioten -materialismoa eta ekonomizismoa gailen ziren gizartean kezka espiritualak eragitea-; Salbatore Mitxelena eta Bitoriano Gandiaga etorkorrago agertu ziren, batez ere sentimendu aldetik, filosofiarenetik baino. Euskal mundu-ikuskera tradizionalean lehen artesi sakonak; politikan, ibili-ibili eginda, ETAren sorrera ahalbidetuko zutenak.

Camus, 1960an hilik, Sartre bilakatu zen erreferente nagusia, bereziki Txillardegirentzat, Bertrand Russelekin batera. Politikoki hark Aljeriako gerrakoan hartutako jarrera, bere aberkide kolonizatzaile frantsesen aurka eta kolonizatu aljeriar musulmanen alde —Camus ez bezala—; Vietnamengo gerran AEBen aurka hartutakoa (Russel tribunala), eta, azkenik, garrantzitsuena, ETAren alde erakutsitakoa 1970ean, Burgosko prozesuarekikoan, erabakigarriak izan ziren.

Artikuluaren mugak kontuan, garatuko ez badugu ere, denok dakigu Txillardegik lehen urteetako ETAn paper garrantzizkoa jokatu zuela, eta, bestalde, eragin zuela Jakineko J. Intxausti eta J. Azurmendirengan-eta - eta alderantziz, jakina-, eta orduko euskal intelligentsian.

1980an, Sartre hiltzean, Euskal Herri penintsularreko erakunde armatuak aldirik aktiboenean zirela, E. Lopez Adan Beltzak berrartu zuen Camusek, L'Homme révolté (1951, Gizon matxinatua) plazaratzean, Sartrerekin biolentzia politiko iraultzailearen legitimotasunaz izandako polemika famatua, 1980ko Euskal Herriko egoera politiko-militarraz hausnartzeko.

Camusen ildotik, Lopez Adanek zapaltzaile zuzenen aurka altxatzeari, haiek zapalkuntza obratzen ari direnean, onargarri zeritzon —esklaboa, eskuan zigorra duela, zigorkatzen diharduen jabearen aurka-, baina, ideologia historiko-ideologiko arrazional baten arabera, zapalkuntzaren erantzule zuzenak ez direnen aurka atentatuak hotzean prestatzea, eta hotzean egitea, ez zitzaion onargarria iruditzen, edo erreparo asko sortzen zizkion behinik behin, galdera moduan planteatuak. Ideala honela planteatzen zuen: «Zapaltzaileen sistema hausteko eraginkortasuna eta erreboltaren etika uztartzerik balego, hori bitartegabeko biolentziaren kasuan izango litzateke posible» (Lopez Adan 2012: 28).

Baina esperantzarik ez zuen egiten; iruditzen zitzaion biolentziaren eginkizun historikoan sinestun zirenek eta norberaren bizia galtzeko arriskua bere gain hartua zutenek ez zutela onartuko ideologiaren esklabo edota jostailu izan zitezkeenik, eta iraultzaren historiak bere barne-tragediaren historia lazgarria izaten jarraituko zuela. 
Lopez Adanengandik Joxe Azurmendirengana etorririk, lehenbizi, honela planteatzen du betiko dilema. Zapalkuntza egoera batean, bortxa ala bortxarik eza da immorala? Biolentzia beti immorala dela esaten bada, hori ez al da immoralitatea estaltzea?, edo behintzat ez al da asmo horrekin egiten? Gaineratzen du kritika horri Camusen inkoherentzia erantsi behar zaiola: moral tradizionalaren kritikarekin hasi eta atzera berriz haraxe itzultzen dela, hots, «absolutu ororen (erlijiosoak, historizistak) kritika indartsuak, inola kuestionatu gabeko balio transhistoriko absolutuen baiespenetik egiten dituela (Egia, Justizia, Solidaritatea, Askatasuna)» (Azurmendi 2011: 99-100). Bestela esanda, Camusentzat Jainkoa ez zela hil.

Polemika katramilatsu bezain hunkigarri eta dorpe hartatik kontsolagarriena iruditzen zaio Azurmendiri Sartre eta Camus biak ere haztamuka ikustea euren bilakabidean, aterabide ziurrik gabe. Biolentziarekiko moralik ez dago egina, ez daude idatziak hamar manamendu eternalak harrizko taulan per secula seculorum, beti egiteko dago, eta gizarte eta aro historiko bakoitzak erabaki behar du egin ala ez.

\section{Erreferentziak}

AizPuru, Alaitz. 2016. Joxe Azurmendi 60ko poesiaren eraberritzean. Ea: HEA. Gabriel Arestiren Etxea.

Aronson, Ronald. 2006. Camus y Sartre. Valentzia: PUV.

AzURMENDI, Joxe. 1998. Oraingo gazte eroak. Irun: Luma.

AzURMENDI, Joxe. 2011. Euskal Herria: Errealitatea eta utopia. Donostia: Elkar.

BASTARRIKA, Iñaki. 1956. «Gizona izaten - Aburuaren oinarria». Yakin 1: 39-47.

BASTARRIKA, Iñaki. 1957a. «Albert Camus edo gizatasun etsia». Yakin 5: 51-60.

BASTARRIKA, Iñaki. 1957b. «Txillardegi jaunari». Yakin 5: 99-102.

Camus, Albert. 1942. L'Étranger. Paris: Éditions Gallimard. Euskarazko itzulpenak: Xabier Galarreta. 2000. Alegia: Hiria eta Josu Zabaleta. 2017. Donostia: Erein.

Camus, Albert. 1942. Le mythe de Sisyphe. Paris: Éditions Gallimard. Euskarazko itzulpena: Xabier Kintana. 1992. Bilbo: Klasikoak.

CAmus, Albert. 1947. La peste. Paris: Editions Gallimard. Euskarazko itzulpena: Imanol Tapia. 1992. Euba: Ibaizabal.

CAMUS, Albert. 1949. Les justes. Paris: Éditions Gallimard.

CAMus, Albert. 1951. L'Homme révolté. Paris: Éditions Gallimard.

CAmus, Albert. 1996. Obras 3. Madril: Alianza. Literatur editorea: José María Guelbenzu.

CoHEn-Solal, Annie. 2005a. Jean-Paul Sartre. Bartzelona: Anagrama.

Cohen-Solal, Annie. 2005b. Jean-Paul Sartre: A life. New York: The New Press.

DE BEAUvorr, Simone. 1947. Pour une morale de l'ambiguïté. Paris: Éditions Gallimard.

ERKIAGA, Eusebio. 1951. «Jean Paul Sartre-ren ardi galduak». Egan 2: 21-22.

GANDIAGA, Bitoriano. 1989. Elorri. Oñati: Arantzazu Frantziskotar Argitaletxea.

IzAGIRRE, Koldo. 2000. Joxe Azurmendi, poesia kaierak. Zarautz: Susa.

LOPEZ ADAN, Emilio. 2012. ETAren estrategia armatuaren historiaz. Baiona: Maiatz.

Merleau-PonTY, Maurice. 1947. Humanisme et terreur. Paris: Éditions Gallimard. 
MitXeLENA, Salbatore. 1958. Unamuno ta abendats. Baiona: Darracq.

Mumma, Howard. 2005. El existencialista hastiado. Conversaciones con Albert Camus. Madril: Vozdepapel.

ORIXE. 1954. «Izatena ta gertatzena: Sartre, Heidegger, Zubiri». Euzko-Gogoa 3-4: 63-66.

ORIXE. 1956. AUGUSTIN GURENAREN AITORKIZUNAK. ZARAUTZ: ITXAROPENA.

SARTRE, Jean-Paul. 1938. La nausée. Paris: Éditions Gallimard. Euskarazko itzulpena: Monika Etxebarria. 2003. Irun: Alberdania; Donostia: Elkar.

SARTRE, Jean-Paul. 1939. Le Mur. Paris: Éditions Gallimard. Euskarazko itzulpena: Mikel Lasa. 1980. Donostia: Kriselu.

SARTRE, Jean-Paul. 1943. L'etre et le néant. Paris: Éditions Gallimard.

SARTRE, Jean-Paul. 1946. L'existentialisme est un humanisme. Euskarazko itzulpena: Juana Atxabal. 1988. Donostia: Kriselu. Gaztelaniazko itzulpena: José María Ortega Ortiz eta Victoria Prati de Fernández. 1984. Bartzelona: Orbis.

SARTRE, Jean-Paul. 1948. Les mains sales. Paris: Les Temps Modernes.

SARTRE, Jean-Paul. 1951. Le diable et le bon dieu. Paris: Éditions Gallimard.

TXILlARDEGI. 1957a. Leturiaren egunkari ezkutua. Bilbo: Euskaltzaindia.

TXILLARDEGI. 1957b. «Taupadak». Euzko-Gogoa, uztaila-abuztua: 63-68. Hemen ere eskuragarri: https://www.jakin.eus/digitalizazioa/txillardegi.

TXILLARDEGI. 1958. «Iñaki Bastarrika'ko jaunari erantzuna». Yakin 6: 85-93. Hemen ere eskuragarri: https://www.jakin.eus/digitalizazioa/txillardegi.

TXILLARDEGI. 1960. «Lekuko bikain bat hil da». Egan 1-2: 52-58. Hemen ere eskuragarri: https://www.jakin.eus/digitalizazioa/txillardegi.

TXILLARDEGI. 1964. «Sartre'ren ukoaZ». Zeruko Argia, 1964-XI-18. Berrargitaratua in Luis Haranburu Altuna. 1985. Gertakarien lekuko, 88-92.

TXillardegi. 1980. «Sartre: Lekuko eta gidaria». In Jean Paul Sartre, Paretaren kontra. Donostia: Kriselu, 7-20. Hemen ere eskuragarri: https://www.jakin.eus/ digitalizazioa/txillardegi

Txillardegi. 1994. Euskal Herria helburu. Tafalla: Txalaparta. Hemen ere eskuragarri: https://www.jakin.eus/digitalizazioa/txillardegi.

TXILlardegi. 2007. Horretaz. Donostia: Elkar. Hemen ere eskuragarri: https://www. jakin.eus/digitalizazioa/txillardegi

ZAITEGI, Jokin. 1951. «Heidegger'en azalkizunak». Euzko-Gogoa 1-2: 25-28. Hemen ere eskuragarri: https://andima.armiarma.eus/eugo/eugo08/eugo0819.htm 